\title{
Thiol-disulfide proteins of stallion epididymal spermatozoa
}

\author{
G.M. Dias ${ }^{a}$, M.L. López ${ }^{a}{ }^{*}$, A.T.S. Ferreira $^{\mathrm{b}}$, D.A. Chapeaurouge ${ }^{\mathrm{b}}$, A. Rodrigues $^{\mathrm{a}}$, \\ J. Perales ${ }^{b}$, C.A. Retamal ${ }^{\text {a }}$ \\ a Laboratório de Biologia Celular e Tecidual, Centro de Biociências e Biotecnologia, UENF, Campos dos Goytacazes, RJ, Brazil \\ b Laboratório de Toxinologia, Instituto Oswaldo Cruz, Fiocruz, Rio de Janeiro, Brazil
}

\section{A R T I C L E I N F O}

\section{Article history:}

Received 20 September 2013

Received in revised form

14 December 2013

Accepted 17 December 2013

Available online 31 December 2013

\section{Keywords:}

Equus caballus spermatozoa

Sperm maturation

Sulphydrylated proteins

Thiol oxidation

\begin{abstract}
A B S T R A C T
Thiol groups of cysteine residues represent redox centers involved in multiple biological functions. It has been postulated that changes in the redox status of mammalian epididymal spermatozoa contribute to the sperm maturation process. The present work shows the thiol-disulfide protein profile of stallion epididymal spermatozoa achieved by twodimension electrophoresis and MALDI-TOF/TOF mass spectrometry of proteins labeled with a thiol-reactive fluorescent tag, monobromobimane. Our results have shown the formation of disulfide bonds in several sperm protein fractions during the epididymal maturation process. The majority of the oxidized thiol sperm proteins identified correspond to structural molecules of the flagellum (as the outer dense fiber-1 protein - ODF1), followed by glycolytic enzymes (as glyceraldehyde-3-phosphate dehydrogenase spermatogenic), antioxidant protectors (as glutathione S-transferase and phospholipid hydroperoxide glutathione peroxidase - PHGPX). The magnitude of the thiol oxidation differs between proteins, and was more drastic in polypeptides with molecular weights of up to $33 \mathrm{kDa}$, identified as ODF1 and PHGPx. A kinase anchor protein, a voltage-dependent anion channel protein and a zona pellucida-binding protein were also found in the polypeptide samples that contained oxidized - $\mathrm{SH}$ groups. These proteins may be modified or controlled by the mechanisms involved in the cysteine-redox changes, corroborating the belief that a correct degree of protein oxidation is required for the stabilization of sperm structure, protection against oxidative damage, induction of progressive sperm motility and fertilization.
\end{abstract}

Published by Elsevier B.V.

\section{Introduction}

The thiol groups of cysteine residues represent redox centers involved in protein structure, enzyme catalysis, signal transduction and regulation of the transcriptional activity of different cell types (Barford, 2004; Fomenko et al., 2008; Jones, 2010). The redox-based regulation of gene expression has emerged as a fundamental regulatory mechanism in cell biology. A variety of proteins, including transcription factors, molecular chaperones, protein

\footnotetext{
* Corresponding author. Tel.: +55 2227234705 .

E-mail addresses: mlopez@uenf.br, mlopezuenf@gmail.com (M.L. López).
}

tyrosine phosphatases and protein tyrosine kinases, are activated or regulated via redox processes. Conformational changes and/or other post-translational modifications may result from the oxidation of thiols within the protein itself or belonging to interacting proteins, thus mediating diverse responses according to the cell physiological state (Jones, 2010; Monteiro et al., 2008; Sen, 2000).

During the epididymal transit, spermatozoa complete a maturation process that enables these cells to interact with the oocyte at the appropriate time and place. This process is the result of a complex cascade of posttranslational changes that involve the rearrangement of the sperm membrane components, the induction of chromatin condensation, the stabilization of the tail components, the processing of different proteins and others modifications 
that lead to the acquisition of motility and the development of the fertilization potential (Cornwall, 2009). It has been postulated that a correct degree of protein - SH oxidation is required not only for these maturation events, but also to prevent oxidative damage that can leads to infertility (Aitken and Vernet, 1998; Dias et al., 2006; Seligman et al., 2005, 2004; Shalgi et al., 1989).

In stallions, we have demonstrated differences in the nuclear and plasma membrane characteristics of spermatozoa obtained from the caput, corpus and cauda regions of the epididymis (Dias et al., 2006; López and De Souza, 1991; López et al., 1987, 2007; Retamal et al., 2000, 2012). The highly packed chromatin of the mature sperm results from changes in the thiol-disulfide status of this structure. The nuclei of immature sperm cells, obtained from the ductuli efferentes, contain mostly thiol groups belonging to cysteine residues, while in mature cells, obtained from the cauda epididymides, these groups are oxidized. Concomitantly, a reduction in the $\mathrm{Zn}^{2+}$ content which favors the oxidation of the $-\mathrm{SH}$ groups was observed. Thus, $\mathrm{Zn}^{2+}$ binding sites of sulphydrylated proteins could be related with the redox sensitivity of the protein (Dias et al., 2006). Recently, it has been suggested that zinc can occupy multiple sites in redox sensitivity proteins, increasing the susceptibility of zinc coordinating cysteine residues to oxidation (Heo et al., 2013).

Although there is some evidences of a functional role for the cysteine modifications, the identity, the significance of most protein thiol alterations and the pathway involved in the physiological sperm thiol oxidation in the epididymis remain unknown. The present work describes the thiol-disulfide protein profile of stallion epididymal spermatozoa achieved by two-dimension gel electrophoresis (2D-PAGE) and matrix-assisted laser desorption/ionization time of flight/time of flight (MALDI TOF/TOF) mass spectrometry. The redox changes of cysteine residues of sperm proteins occurring during the epididymal transit are highlighted.

\section{Materials and methods}

\subsection{Chemicals}

Chemicals were obtained from Sigma Chemical Company (St. Louis, MO, USA) and Merck AG (Darmstadt, Germany). Reagents for electrophoresis were purchased from Bio-Rad Laboratories (Richmond, CA).

\subsection{Sample collection and processing}

The epididymides were obtained by surgical castration from six healthy mature stallions, aged between 3 and 8 years old, according procedures described in McKinnon et al. (2011). The connective tissue and superficial blood vessels surrounding the epididymis were removed through careful dissection. The caput, corpus and cauda epididymal regions were separated, gently minced and squeezed in phosphate buffered saline (PBS) $\mathrm{pH}$ 7.2. The luminal content released from each epididymal region was centrifuged at $760 \times \mathrm{g}$ for $30 \mathrm{~min}\left(4^{\circ} \mathrm{C}\right)$. The pellets obtained were resuspended with an erythrocyte lysis solution $(0.2 \mathrm{M}$
$\mathrm{NH}_{4} \mathrm{Cl}, 0.1 \mathrm{M} \mathrm{KHCO}_{3}, 0.1 \mathrm{M}$ EDTA), incubated in an ice bath for $5 \mathrm{~min}$ and centrifuged $\left(760 \times \mathrm{g}\right.$ for $10 \mathrm{~min}$ at $\left.4{ }^{\circ} \mathrm{C}\right)$. The supernatants above the sperm pellets were removed and discarded. Afterward, the spermatozoa were gently resuspended in PBS and centrifuged again like described above. This washing procedure was done three times before the subsequent processing.

\subsection{Labeling of the thiol groups with $\mathrm{mBBr}$}

Epididymal sperm samples were treated with monobromobimane ( $\mathrm{mBBr}$ ) (Calbiochem, San Diego, CA, USA) following a previously described protocol (Dias et al., 2006; Kosower and Kosower, 1987). This procedure allows the determination of the $-\mathrm{SH}$ and $\mathrm{S}-\mathrm{S}$ bonds (after the reduction of S-S by dithiothreitol [DTT]). Briefly, the washed epididymal spermatozoa were incubated in PBS with and without $1 \mathrm{mM}$ DTT for $10 \mathrm{~min}$. Afterward, the sperm cells were incubated with $2 \mathrm{mM}$ of $\mathrm{mBBr}$-solution (prepared from a stock solution of $50 \mathrm{mM} \mathrm{mBBr}$ in acetonitrile [ACN]) for 20 min and washed twice in PBS.

\subsection{Protein extraction and gel electrophoresis assays}

Sperm proteins were obtained by sonication in a $5 \%$ sodium dodecyl sulfate (SDS) and $1 \mathrm{mM}$ DTT (1:2) solution for one-dimension polyacrylamide gel electrophoresis (1D-PAGE), and in a $20 \mathrm{mM}$ Tris- $\mathrm{HCl}, 4 \%$ triton $\mathrm{X}-100,8 \mathrm{M}$ urea, and $30 \mathrm{mM}$ DTT solution for 2D-PAGE assays. After the addition of protease inhibitors ( $10 \mathrm{mM}$ ethylenediaminetetraacetic acid (EDTA), $1 \mathrm{mM}$ phenylmethylsulfonyl fluoride (PMSF), $4 \mu \mathrm{M}$ bestatin hydrochloride), the samples were sonicated at $10 \mathrm{~W}$ with a Sonic Dismembrator (model F60Thermo Fisher Scientific, Rockford, IL, USA) for 10 cycles of $30 \mathrm{~s}$ in an ice bath, and then centrifuged $(15,000 \times \mathrm{g})$ for $30 \mathrm{~min}$ at $4{ }^{\circ} \mathrm{C}$. The supernatant containing the solubilized sperm proteins was stored at $-70^{\circ} \mathrm{C}$ for further analysis.

1D-PAGE: Equal amounts of the thiol-labeled sperm proteins from the caput, corpus and cauda epididymal regions were subjected to $12-20 \%$ denaturing gradient gel electrophoresis (DGGE) under reducing (10\% $\beta$-mercaptoethanol) conditions. The electrophoresis was performed in mini-gels using the Mini-Protean III system (Bio-Rad Laboratories, Hercules, CA, USA). After electrophoresis, the gels were thoroughly washed in distilled water and photographed using a UV-light transilluminator $(312 \mathrm{~nm})$ coupled to a photographic camera. The gels were stained with Coomassie brilliant blue (CBB) in $40 \% \mathrm{v} / \mathrm{v}$ methanol and $10 \% \mathrm{v} / \mathrm{v}$ acetic acid and then destained in the same solution without CBB. Molecular weight marker kits (Bio-Rad Laboratories, Hercules, CA, USA), ranging from 6.5 to $200 \mathrm{kDa}$, were used as standards. The relative amount of protein was quantified by densitometry, using a computational program, from a TIFF gray image obtained with a commercial scanner at 400 dpi. The "Gel Perfect" software calculated the relative mobility of each stained band and the area occupied by it, and provided a diagrammatic presentation of the protein bands and their relative concentrations in relation to the total protein content by lane (Retamal et al., 1999). 
2D-PAGE: The sperm protein extracts were precipitated with acetone (3:1) for at least $2 \mathrm{~h}$ at $-20^{\circ} \mathrm{C}$. After centrifugation $\left(15,000 \times \mathrm{g}\right.$ for $40 \mathrm{~min}$ at $\left.4{ }^{\circ} \mathrm{C}\right)$, the pellets were resuspended in a $30 \mathrm{mM}$ Tris- $\mathrm{HCl}$ buffer ( $\mathrm{pH} 7.1$ ) containing $4 \%$ triton X-100, $8 \mathrm{M}$ urea and $30 \mathrm{mM}$ DTT. An aliquot of this sample ( $\sim 100 \mu \mathrm{g}$ of protein) was diluted in a rehydration buffer containing 2\% CHAPS, $8 \mathrm{M}$ urea, $0.2 \%$ DTT, $0.5 \%$ ampholytes ( $\mathrm{pH} 3-10$ ) and $0.002 \%$ bromophenol blue in a total volume of $125 \mu \mathrm{L}$. The samples were applied to ready immobilized pH gradients (IPG) strips (GE Healthcare, Little Chalfont, UK) ranging from $\mathrm{pH} 3$ to 10 and $\mathrm{pH} 4$ to 7 , and rehydrated for $16 \mathrm{~h}\left(25^{\circ} \mathrm{C}\right)$. The isoelectric focusing was performed at up to $\sim 7000 \mathrm{~V} / \mathrm{h}$ with an Ettan IPGPhor 3 system (GE Healthcare). After the first dimension, the strips were incubated for $15 \mathrm{~min}$ in a solution of $50 \mathrm{mM}$ Tris- $\mathrm{HCl}$ (pH 8.8), $6 \mathrm{M}$ urea, 30\% v/v glycerol, and 1\% DTT and then in the same buffer with $2.5 \%$ iodoacetamide instead of DTT, to allow cysteine alkylation. For the second dimension, each strip was placed onto a $12 \%$ polyacrylamide gel and sealed with $0.5 \%$ agarose in a solution of $250 \mathrm{mM}$ Tris- $\mathrm{HCl} \mathrm{pH} 8.3$, $14.2 \%$ glycine, $1 \%$ SDS, and $0.002 \%$ bromophenol blue and subjected to a vertical electrophoresis at $25 \mathrm{~mA}$. To visualize the sulphydrylated proteins, gels were photographed under UV radiation, stained with CBB R-250 and scanned at $400 \mathrm{dpi}$. Images of 2D-gels were analyzed with the ImageMaster 2D Platinum v7.0 (GE Healthcare).

\subsection{In-gel protein digestion}

Selected protein spots were removed from 2D-gels and placed into microcentrifuge tubes, washed with deionized water, dehydrated with $100 \%$ ACN and dried with a speed vacuum centrifuge (Savant Speed-Vac, Thermo Fisher Scientific, Rockford, IL, USA) for $15 \mathrm{~min}$. Polypeptides were digested with $15 \mu \mathrm{L}$ of sequencing-grade trypsin $(33 \mathrm{ng} / \mu \mathrm{L}$ of trypsin in $50 \mathrm{mM}$ of ammonium bicarbonate, $\mathrm{pH} 8.0$ ) (Promega, Madison, WI, USA) for $30 \mathrm{~min}$ in a $58^{\circ} \mathrm{C}$ water bath. Tryptic peptides were extracted from gels with $30 \mu \mathrm{L}$ of $5 \%$ formic acid in $50 \%$ ACN using agitation followed by ultrasonication (10 min). The extraction step was repeated twice. The samples were concentrated with a Speed-Vac, without heat, and desalted with Zip-Tip $\mathrm{C}_{18}$ tips (Millipore, Billerica, MA, USA) prior to the MS analysis.

\subsection{MALDI TOF-TOF mass spectrometry}

Mixtures of $0.2 \mu \mathrm{L}$ of extracted peptide solution and $0.2 \mu \mathrm{L}$ of matrix ( $\alpha$-cyano-4-hydroxycinnamic acid, $10 \mathrm{mg} / \mathrm{mL}$ in $50 \%$ ACN/0.1\% TFA) were spotted onto an OptiTOF 384-well plate, allowed to dry at room temperature (dried-droplet method) and finally loaded into the mass spectrometer. The acquisition of the raw data was accomplished using an ABSciex TOF/TOF 5800 mass spectrometer (ABSciex, Foster City, CA, USA) operated in the reflector mode. The mass spectra were acquired (MS and MS/MS) using an Optibeam laser with a $1-\mathrm{kHz}$ repetition rate. The most intense ion signals (up to 15) in the MS spectra were selected as the precursors for the following MS/MS acquisition. An external calibration was performed in the MS mode using a mixture of five peptides, including des-Arg1Bradykinin ( $m / z$ 904.468), angiotensin I ( $m / z$ 1296.685),
Glu1-fibrinopeptide B ( $m / z$ 1570.677), ACTH (18-39) $(m / z$ $2465.199)$, and $A C T H$ ( $7-38 \mathrm{clip})(\mathrm{m} / z$ 3,657.9294). In addition, MS/MS spectra were externally calibrated using the fragment-ion masses observed in the MS/MS spectrum of the Glu1-fibrinopeptide B.

\subsection{Data analysis}

MS/MS mass spectra were analyzed using the MASCOT software (version 1.5; Matrix Science, Boston, MA, USA) and the NCBI non-redundant database with mammalian taxonomy filters. In addition, we analyzed the MS/MS mass spectra using an in-house created database (Equus, 25,000 sequences). The variable modifications of the peptides included cysteine (carbamidomethylated or modified by bromobimane), glutamine (pyro-Q), glutamic acid (pyro$\mathrm{N}$ ) and methionine (oxidation) in all the database searches. Two missed cleavages per peptide were allowed, and a mass tolerance of 0.3 Da for both the MS and MS/MS spectra was applied. Finally, the peptide sequences identified by MASCOT were validated using the Scaffold software (version 03_03_02, Proteome Software Inc., Portland, OR, USA).

\subsection{Analysis of $\mathrm{mBBr}$-labeled peptides}

The $\mathrm{mBBr}$ labeling was confirmed by methodology described by Petrotchenko et al. (2006). mBBr-labeled peptides were identified by MALDI MS. Peptides with a mBBr-modified cysteine have increasing in their signal in $190 \mathrm{Da}$ when compared with the free-cysteine peptide due to a partial fragmentation of the $\mathrm{mBBr}$-bound peptide under MALDI conditions. Modification of the peptides was further confirmed by the presence of the specific immonium ion for the mBBr-modified cysteine residues at $\mathrm{m} / \mathrm{z}$ 266.6 in MS/MS sprectrum, followed by manual matching of these peptides against the predicted peptide fragmentation spectra generated by MS-Product (Protein Prospector). Moreover, the peptide sequences and final confirmation of the $\mathrm{mBBr}$ modification were obtained by de novo sequencing considering the mass of $\mathrm{mBBr}-\mathrm{Cys}$ of $293 \mathrm{Da}$.

\section{Results}

\subsection{Protein analysis by $1 D-S D S-P A G E$}

1D-12-20\% DGGE of stallion sperm proteins, conducting under denaturing and reducing conditions, revealed several CBB staining bands of different intensity ranging from 200 to $<20 \mathrm{kDa}$. Differences in the electrophoretic mobility and relative concentration of some bands were observed in sperm samples obtained from the caput, corpus and cauda epididymal regions. The electrophoretic analysis of the sperm labeled with $\mathrm{mBBr}$ showed that several protein bands corresponded to sulphydrylated proteins (Fig. 1A and B). A consistent pattern was observed in the electrophoretic profile of all studied animals. The fluorescence pattern of the DTT pre-treated and non-treated sperm samples were compared in the same SDS-PAGE. Despite some differences, spermatozoa obtained from the caput, corpus and cauda epididymal regions shared at least fourteen welldefined fluorescent bands $(107,81,71,65,58,53,45,41,34$, 

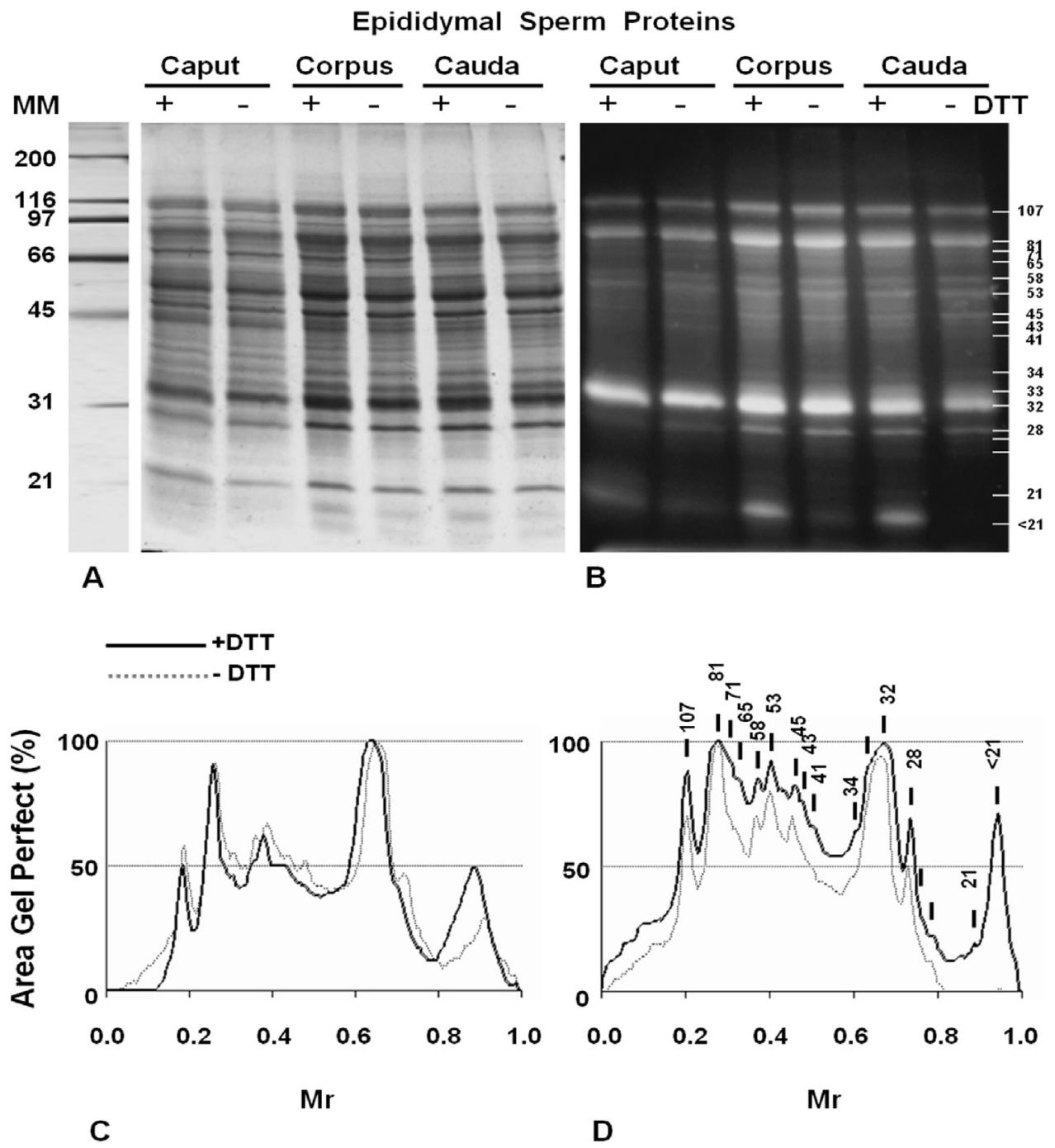

Fig. 1. Representative one-dimensional 12-20\% DGGE of sperm extracted proteins, obtained from the caput, corpus and cauda epididymal regions. The spermatozoa were pre-treated (+) or not (-) with DTT; prior to the thiol group labeling with the fluorescent agent mBBr. (A) Coomassie Blue R-250 staining. (B) The corresponding UV fluorescence image of the mBBr-labeled spermatozoa. Comparatives densitograms (negative image) showing the fluorescent pattern of sperm proteins obtained from the caput (C) and cauda (D) epididymal regions treated and not treated with DTT. MW: molecular weight marker. Mr: relative mobility.

$33,32,28,27,26 \mathrm{kDa}$ ), among which those at $\sim 81,32 \mathrm{kDa}$ and $<21 \mathrm{kDa}$ displayed the highest fluorescence, indicating a high level of sulphydrylation (Fig. $1 \mathrm{~A}$ and $\mathrm{B}$ ). The DTT-reducing treatment of the sperm cells, prior to the thiol-group labeling, resulted in an increase in the fluorescence signal of almost all of the electrophoretic bands in the samples obtained from the cauda epididymal region, especially in those with a $\mathrm{Mr}$ lower than $33 \mathrm{kDa}$. In contrast, the samples obtained from the caput region were less affected by the DTT treatment (Fig. 1C and D). These data indicate that some of the sperm thiol proteins that contained free $-\mathrm{SH}$ groups in the caput epididymal region were modified by the formation of internal disulfides along the epididymis. All procedures involving animals were approved by the Ethics Committee on Animal Use of the Universidade Estadual do Norte Fluminense.

\subsection{Disulfide proteomic analysis of the stallion spermatozoa}

The 2D-PAGE approach, using the linear pH 3-10 IPG strips in the first dimension followed by $12 \%$ SDS-PAGE for the second dimension, resolved more than 230 protein spots in samples obtained from the cauda epididymis region. The fluorescence signal of $\mathrm{mBBr}$-labeled proteins revealed that approximately $18 \%$ of these protein spots displayed the mBBr labeling (Fig. 2). A consistent pattern was also observed in the 2D-electrophoretic profile of all samples analyzed. The fluorescent 2D-spots of DTTtreated sperm samples were matched with those spots of the sperm samples with non reducing-treatment and analyze them all by MALDI-TOF/TOF mass spectrometry. The mass of $\mathrm{mBBr}$ was checked in peptides from fluorescent 


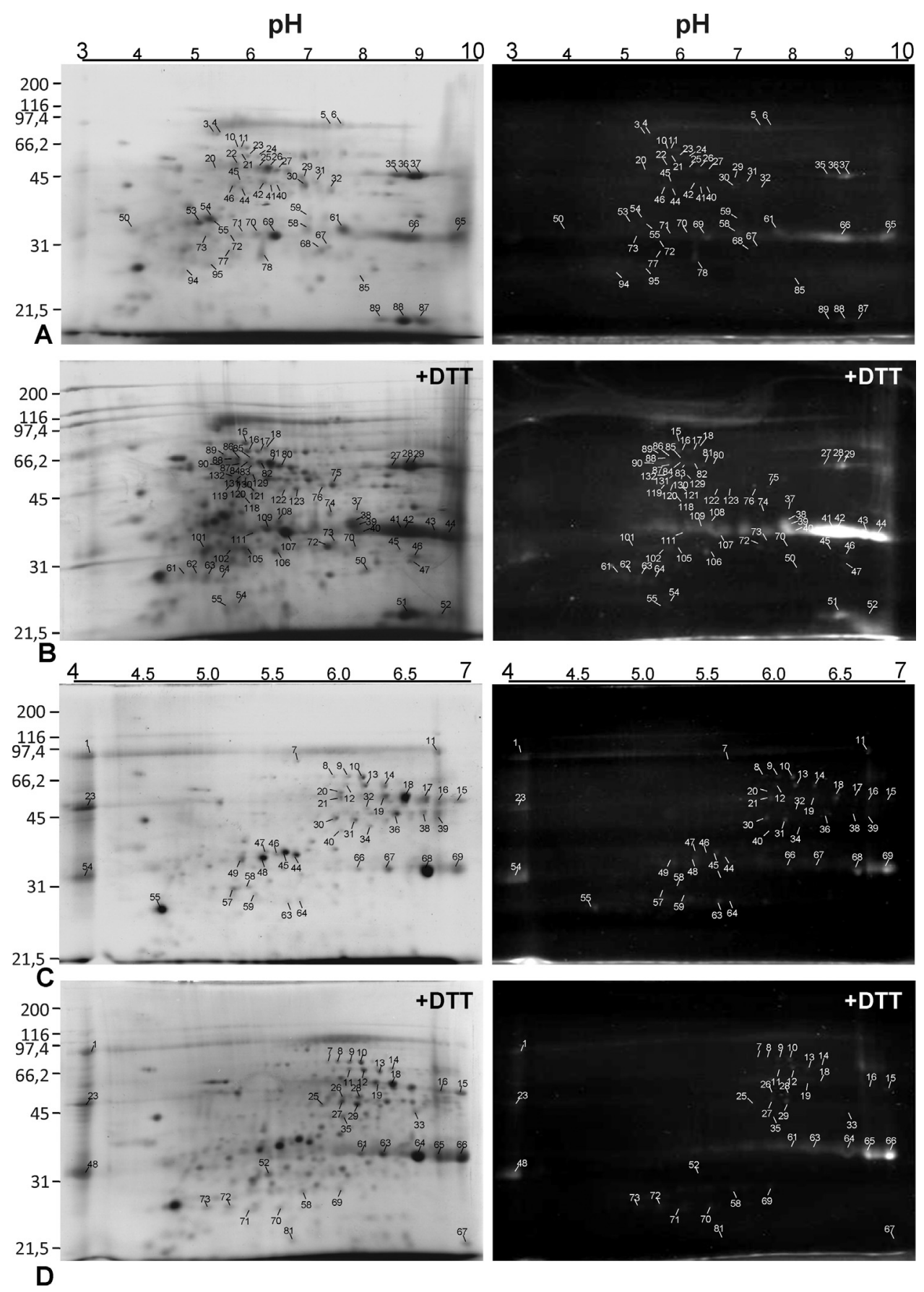

Fig. 2. Analytical two-dimensional electrophoresis of sperm proteins, obtained from the cauda epididymal region spermatozoa, labeled with mBBr. Gels stained with $\mathrm{CBB}$ are on the left panels. On the right panels, the same gels, photographed under a UV-light transilluminator, showing the thiol positive proteins. A and C show representatives 2D-gels, without pre-treatment with DTT-IPG 3 to 10 and 4 to 7 respectively. B and D represent 2D-PAGE of samples pre-treated with DTT. Numbers along the top denote the $\mathrm{pH}$ gradient. Values on the left side represent relative molecular weights. The numbered fluorescent spots were extracted and identified by MS and de novo sequencing.

spot samples as already described. Among $\sim 64$ fluorescent spots of DTT-treated samples (IPG 3-10), the mBBr labeling was undoubtedly confirmed in 28 spots. In $\mathrm{pH} 4-7$ range, 36 fluorescent spots were identified in the same sample, of which the $\mathrm{mBBr}$ labeling could be determined in 18 spots (Fig. 2, Table 1).
In sperm protein samples with $S-S$ reducing pretreatment, the majority of mBBr-labeled proteins identified were related to cytoskeleton structure such as outer dense fiber 1 (ODF1 - 18 spots) and a-kinase anchor protein4 (AKAP4 - 13 spots), followed by glycolytic enzyme, as the glyceraldehyde-3-phosphate dehydrogenase 
Table 1

Identification of mBBr-labeled proteins of stallion epididymal spermatozoa (with and without DTT pre-treatment) by MS/MS.

\begin{tabular}{|c|c|c|c|c|c|c|c|c|}
\hline Spot ID & $\begin{array}{l}\text { Mascot } \\
\text { identification }\end{array}$ & Spot match ${ }^{a, b}$ & $\begin{array}{l}\text { Mascot } \\
\text { identification }\end{array}$ & $\begin{array}{l}\text { MBBr-labeled } \\
\text { peptide }^{c}\end{array}$ & $\begin{array}{l}\text { Free-Cys } \\
\text { peptide }\end{array}$ & $\begin{array}{l}\text { MBBr-labeled peptide } \\
\text { Sequence }\end{array}$ & $\begin{array}{l}\text { Blast } \\
\text { search }\end{array}$ & $\begin{array}{l}\text { Accession } \\
\text { number }\end{array}$ \\
\hline \multicolumn{2}{|c|}{ +DTT/Gel B } & -DTT/Gel A & & & & & & \\
\hline \multirow[t]{2}{*}{$27 \mathrm{~B}$} & GAPDHS & $35 \mathrm{~A}$ & GAPDHS & 1002.50 & 812.43 & QPCPVIR & GAPDHS & 338709945 \\
\hline & & & & 1952.98 & 1762.90 & VSNASCTTNCLAPLAK & GAPDHS & \\
\hline $28 \mathrm{~B}$ & GAPDHS & $36 \mathrm{~A}$ & GAPDHS & 1002.5 & 812.42 & QPCPVIR & GAPDHS & 338709945 \\
\hline \multirow[t]{3}{*}{$29 B$} & GAPDHS & $37 \mathrm{~A}$ & GAPDHS & 1002.5 & 812.43 & QPCPVIR & GAPDHS & 338709945 \\
\hline & & & & 1690.87 & 1500.92 & VPTPDVSVVDLTCR & GAPDHS & \\
\hline & & & & 1952.98 & 1762.90 & VSNASCTTNCLAPLAK & GAPDHS & \\
\hline \multirow[t]{2}{*}{ 37B } & LDHC & $62 \mathrm{~A}$ & LDHC & 1126.52 & 936.45 & CIDELSTR & ODF1 & 149721588 \\
\hline & VDAC-2 & & & 1379.7 & 1189.62 & LALSCLLDSVR & ODF1 & \\
\hline \multirow[t]{2}{*}{ 38B/39B } & VDAC-2 & $61 \mathrm{~A}$ & VDAC-2 & 1126.5 & 936.43 & CIDELSTR & ODF1 & 149721588 \\
\hline & & & & 1379.68 & 1189.64 & LALSCLLDSVR & ODF1 & \\
\hline \multirow[t]{2}{*}{$40 B$} & GAPDHS & & & 1002.51 & 812.41 & QPCPVIR & GAPDHS & 338709945 \\
\hline & & & & 1379.69 & 1189.62 & LALSCLLDSVR & ODF1 & 149721588 \\
\hline \multirow[t]{3}{*}{$41 \mathrm{~B} / 42 \mathrm{~B}$} & ODF1 & $66 \mathrm{~A}$ & GAPDHS & 1952.95 & - & VSNASCTTNCLAPLAK & GAPDHS & 338709945 \\
\hline & & & & 1126.64 & 936.56 & CIDELSTR & ODF1 & \\
\hline & & & & 1379.85 & 1189.75 & LALSCLLDSVR & ODF1 & 149721588 \\
\hline \multirow[t]{2}{*}{$43 B$} & ZPBP & & & 1126.51 & 936.44 & CIDELSTR & ODF1 & 149721588 \\
\hline & & & & 1379.68 & 1189.61 & LALSCLLDSVR & ODF1 & \\
\hline \multirow[t]{2}{*}{ 44B } & ODF1 & $65 \mathrm{~A}$ & VDAC-3 & 1126.64 & 936.55 & CIDELSTR & ODF1 & 149721588 \\
\hline & VDAC-3 & & & & & & & \\
\hline $46 \mathrm{~B}$ & GAPDHS & & & 1952.93 & 1762.83 & VSNASCTTNCLAPLAK & GAPDHS & 338709945 \\
\hline $50 \mathrm{~B}$ & GAPDHS & $85 \mathrm{~A}$ & GAPDHS & 1002.48 & 812.42 & QPCPVIR & GAPDHS & 338709945 \\
\hline $51 \mathrm{~B}$ & PHGPx & $88 \mathrm{~A}$ & PHGPX & 1001.44 & 811.37 & YAECGLR & PHGPx & 14971097 \\
\hline \multirow[t]{2}{*}{$52 \mathrm{~B}$} & GAPDHS & & & 1002.45 & 812.40 & QPCPVIR & GAPDHS & 338709945 \\
\hline & OXCT2 & & & 1952.90 & - & VSNASCTTNCLAPLAK & GAPDHS & \\
\hline 61B & AKAP4 & & & 1099.49 & 909.41 & LPSGNCYR & AKAP4 & 149744514 \\
\hline & TUBB-2C & & & & & & & \\
\hline $62 \mathrm{~B}$ & AKAP4 & & & 1099.48 & 909.41 & LPSGNCYR & AKAP4 & 149744514 \\
\hline & TUBB-2C & & & & & & & \\
\hline $63 B$ & AKAP4 & $94 \mathrm{~A}$ & AKAP4 & 1099.53 & 909.53 & LPSGNCYR & AKAP4 & 149744514 \\
\hline & & & ROPN1L & 1900.89 & 1710.96 & IVCEVLSSDHDSGPPR & ROPN1L & 149731547 \\
\hline 64B & AKAP4 & & & 1173.53 & 983.46 & TEGSVCLFK & AKAP4 & 149744514 \\
\hline $70 \mathrm{~B}$ & GAPDHS & & & 1002.48 & - & QPCPVIR & GAPDHS & 338709945 \\
\hline & TIM & & & & & & & \\
\hline 72B & GAPDHS & $68 \mathrm{~A}$ & GAPDHS & 1690.81 & 1500.74 & VPTPDVSVVDLTCR & GAPDHS & 338709945 \\
\hline & & & & 1952.93 & 1762.84 & VSNASCTTNCLAPLAK & GAPDHS & \\
\hline 73B & GAPDHS & $67 \mathrm{~A}$ & CRISP2 & 1952.96 & - & VSNASCTTNCLAPLAK & GAPDHS & 338709945 \\
\hline & & & GAPDHS & & & & & \\
\hline $102 B$ & AKAP4 & & & 1099.48 & 909.40 & LPSGNCYR & AKAP4 & 149744514 \\
\hline & TUBB-2C & & & & & & & \\
\hline $106 \mathrm{~B}$ & GSTM3 & $78 \mathrm{~A}$ & GSTM3 & 1479.55 & 1289.48 & YTCGEAPDYDR & GSTM3 & 194211022 \\
\hline & & & & 1231.60 & 1041.59 & LCYSADLEK & GSTM3 & \\
\hline & & & & 1268.62 & 1078.63 & CLDEFPNLK & GSTM3 & \\
\hline 107B & TIM & $69 A$ & TIM & 1379.70 & 1189.63 & LALSCLLDSVR & ODF1 & 149721588 \\
\hline & & & & 1126.53 & 936.46 & CIDELSTR & ODF1 & \\
\hline 109B & TIM & $70 \mathrm{~A}$ & TIM & 1379.68 & 1189.62 & LALSCLLDSVR & ODF1 & 149721588 \\
\hline & & & & 1126.51 & 936.44 & CIDELSTR & ODF1 & \\
\hline 111B & TIM & $71 \mathrm{~A}$ & TIM & 1379.66 & 1189.59 & LALSCLLDSVR & ODF1 & 149721588 \\
\hline & & & & 1126.50 & 936.43 & CIDELSTR & ODF1 & \\
\hline 131B & GRP-75 & & & 1379.75 & 1189.74 & LALSCLLDSVR & ODF1 & 149721588 \\
\hline & ODF-2 & & & & & & & \\
\hline +DTT/Gel & & -DTT/Gel C & & & & & & \\
\hline $1 \mathrm{D}$ & ODF-2 & $1 C$ & ODF-2 & 2332.00 & 2141.98 & AVISPGGECSVDDLSFYINR & AKAP4 & 149744514 \\
\hline $15 \mathrm{D}$ & GAPDHS & $15 \mathrm{C}$ & GAPDHS & 1002.47 & 812.40 & QPCPVIR & GAPDHS & 338709945 \\
\hline & & & & 1952.82 & 1762.75 & VSNASCTTNCLAPLAK & GAPDHS & \\
\hline $16 \mathrm{D}$ & GAPDHS & $16 C$ & GAPDHS & 1002.46 & 812.39 & QPCPVIR & GAPDHS & 338709945 \\
\hline & & & & 1952.81 & 1762.75 & VSNASCTTNCLAPLAK & GAPDHS & \\
\hline $23 \mathrm{D}$ & GAPDHS & $23 C$ & GAPDHS & 1002.45 & 812.38 & QPCPVIR & GAPDHS & 338709945 \\
\hline & & & & 1952.79 & 1762.73 & VSNASCTTNCLAPLAK & GAPDHS & \\
\hline 48D & TIM-1 & $54 C$ & TIM & 1126.43 & 936.38 & CIDELSTR & ODF1 & 149721588 \\
\hline & & & VDAC-3 & 1379.59 & 1189.53 & LALSCLLDSVR & ODF1 & \\
\hline $52 \mathrm{D}$ & HSP70 & $58 \mathrm{C}$ & HSP70 & 1099.44 & 909.37 & LPSGNCYR & AKAP4 & 149744514 \\
\hline & AKAP4 & & & & & & & \\
\hline $58 \mathrm{D}$ & AKAP4 & $63 C$ & AKAP4 & 1099.44 & 909.38 & LPSGNCYR & AKAP4 & 149744514 \\
\hline & & & АТР5B & & & & & \\
\hline $61 \mathrm{D}$ & TIM-1 & $66 C$ & TIM & 1126.46 & 936.39 & CIDELSTR & ODF1 & 149721588 \\
\hline & & & & 1379.62 & 1189.56 & LALSCLLDSVR & ODF1 & \\
\hline $63 \mathrm{D}$ & TIM-1 & $67 C$ & TIM & 1379.63 & 1189.56 & LALSCLLDSVR & ODF1 & 149721588 \\
\hline
\end{tabular}


Table 1 (Continued)

\begin{tabular}{|c|c|c|c|c|c|c|c|c|}
\hline Spot ID & $\begin{array}{l}\text { Mascot } \\
\text { identification }\end{array}$ & Spot match ${ }^{\mathrm{a}, \mathrm{b}}$ & $\begin{array}{l}\text { Mascot } \\
\text { identification }\end{array}$ & $\begin{array}{l}\text { MBBr-labeled } \\
\text { peptide }^{c}\end{array}$ & $\begin{array}{l}\text { Free-Cys } \\
\text { peptide }\end{array}$ & $\begin{array}{l}\text { MBBr-labeled peptide } \\
\text { Sequence }\end{array}$ & $\begin{array}{l}\text { Blast } \\
\text { search }\end{array}$ & $\begin{array}{l}\text { Accession } \\
\text { number }\end{array}$ \\
\hline $64 \mathrm{D}$ & TIM-1 & $68 C$ & TIM & $\begin{array}{l}1126.48 \\
1379.64\end{array}$ & $\begin{array}{r}936.41 \\
1189.58\end{array}$ & $\begin{array}{l}\text { CIDELSTR } \\
\text { LALSCLLDSVR }\end{array}$ & $\begin{array}{l}\text { ODF1 } \\
\text { ODF1 }\end{array}$ & 149721588 \\
\hline $65 \mathrm{D}$ & ODF1 & & & $\begin{array}{l}1379.62 \\
1126.54\end{array}$ & $\begin{array}{r}1189.57 \\
936.46\end{array}$ & $\begin{array}{l}\text { LALSCLLDSVR } \\
\text { CIDELSTR }\end{array}$ & $\begin{array}{l}\text { ODF1 } \\
\text { ODF1 }\end{array}$ & 149721588 \\
\hline $66 \mathrm{D}$ & ODF1 & $69 C$ & ODF1 & $\begin{array}{l}1379.62 \\
1126.54\end{array}$ & $\begin{array}{r}1189.57 \\
936.46\end{array}$ & $\begin{array}{l}\text { LALSCLLDSVR } \\
\text { CIDELSTR }\end{array}$ & $\begin{array}{l}\text { ODF1 } \\
\text { ODF1 }\end{array}$ & 149721588 \\
\hline 67D & PHGPx & & & 1001.44 & 811.37 & YAECGLR & PHGPx & 14971097 \\
\hline $69 \mathrm{D}$ & AKAP4 & & & $\begin{array}{l}1099.42 \\
1173.46\end{array}$ & $\begin{array}{l}909.36 \\
983.40\end{array}$ & $\begin{array}{l}\text { LPSGNCYR } \\
\text { TEGSVCLFK }\end{array}$ & $\begin{array}{l}\text { AKAP4 } \\
\text { AKAP4 }\end{array}$ & 149744514 \\
\hline $70 \mathrm{D}$ & AKAP4 & & & $\begin{array}{l}1099.42 \\
1173.46\end{array}$ & $\begin{array}{l}909.36 \\
983.39\end{array}$ & $\begin{array}{l}\text { LPSGNCYR } \\
\text { TEGSVCLFK }\end{array}$ & $\begin{array}{l}\text { AKAP4 } \\
\text { AKAP4 }\end{array}$ & 149744514 \\
\hline $71 \mathrm{D}$ & AKAP4 & & & $\begin{array}{l}1099.43 \\
1173.46\end{array}$ & $\begin{array}{l}909.37 \\
983.40\end{array}$ & $\begin{array}{l}\text { LPSGNCYR } \\
\text { TEGSVCLFK }\end{array}$ & $\begin{array}{l}\text { AKAP4 } \\
\text { AKAP4 }\end{array}$ & 149744514 \\
\hline $72 \mathrm{D}$ & AKAP4 & & & $\begin{array}{l}1099.42 \\
1173.46\end{array}$ & $\begin{array}{l}909.36 \\
983.38\end{array}$ & $\begin{array}{l}\text { LPSGNCYR } \\
\text { TEGSVCLFK }\end{array}$ & $\begin{array}{l}\text { AKAP4 } \\
\text { AKAP4 }\end{array}$ & 149744514 \\
\hline $73 \mathrm{D}$ & $\begin{array}{l}\text { AKAP4 } \\
\text { TUBB-2 }\end{array}$ & & & $\begin{array}{l}1099.45 \\
1173.49\end{array}$ & $\begin{array}{l}909.38 \\
983.43\end{array}$ & $\begin{array}{l}\text { LPSGNCYR } \\
\text { TEGSVCLFK }\end{array}$ & $\begin{array}{l}\text { AKAP4 } \\
\text { AKAP4 }\end{array}$ & 149744514 \\
\hline
\end{tabular}

Abbreviations of protein names in the table: AKAP4, a-kinase anchor protein-4; ATP5B, ATP synthase, H+ transporting, mitochondrial F1 complex, beta polypeptide; CRISP2, cysteine-rich secretory protein 2; GAPDHS, glyceraldehyde-3-phosphate dehydrogenase sperm-specific; GRP-75, stress-70 protein, mitochondrial; GSTM3, glutathione S-transferase M3; HSP70, heat shock 70 kDa protein; LDHC, lactate dehydrogenase C; ODF, outer dense fiber; OXCT2, 3-oxoacid CoA transferase 2; PHGPX, phospholipid hydroperoxide glutathione peroxidase; ROPN1L, ropporin 1-like; TIM, triosephosphate isomerase; TUBB, beta tubulin; VDAC, voltage-dependent anion channel; ZPBP, zona pellucida-binding protein.

a $A, B, C$ or $D$ in the spot name refers to the spot excised from the gels shown in Fig. $2 A, B, C$ and D, respectively.

b 2D-spots of samples without DTT pre-treatment that matched to those 2D-spots of samples pre-treated with DTT.

c The specific immonium ion of mBBr-Cys ( $\mathrm{m} / \mathrm{z} 266.1)$ was detected in all MS/MS spectrum of labeled peptides.

sperm-specific (GAPDHS - 14 spots) and proteins involved in protection strategies such as phospholipid hydroperoxide glutathione peroxidase (PHGPX), glutathione S-transferase M3 (GSTM3) and ropporin 1 (ROPN1) a sperm protein localized in the fibrous sheath of the flagella (Table 1). Some proteins were identified in multiple localizations. Some spots of the same protein differed slightly by their isoelectric point $(\mathrm{p} I)$, suggesting the presence of post-translational modifications. Several spots contained peptides that corresponded to two proteins.

As also observed in 1D-PAGE, the fluorescence signal of spots detected in the cauda epididymal sperm samples increased with the DTT pre-treatment (Fig. 2). This behavior was more marked for spots of up to $\sim 33 \mathrm{kDa}$ such as ODF1 (32 kDa/pI 8.8-9.1), VDAC-2 (33 kDa/pI 8.0), GST (28 kDa/pI 6.6), PHGPx (20kDa/pI 8.9), and AKAP4 (30-26 kDa/pI 4.8-6.0). GAPDHS (45.5 kDa/pI 8.8-9.2) showed the same behavior. The 32-kDa ODF1 was the most $\mathrm{mBBr}$-labeled protein of the sperm homogenate corroborating densitometric analysis of 1D gel, which showed the same behavior of the 32-kDa band. Sequence information of fluorescence spots corresponding AKAP4, ODF-1, GAPDHS, GSTM3, and PHGPx is shown in Tables 1 and 2. The peptides from the cytoskeleton proteins (ODF1 and AKAP4) belong to the N-terminus of the polypeptide chain. These proteins were found in several spots that contained peptides corresponding to others proteins. Just one taggedpeptide of PHGPx was detected.

Approximately 30 different proteins were identified, with a high confidence, in the thiol-positive spot samples, using MALDI TOF-TOF MS (Supplementary data). The majority of fluorescent spots $(53 \%)$ matched to the cytoskeletal proteins. Some of them corresponded to proteins previously reported as accessory structure of the sperm flagellum (e.g. ODF2 in the outer dense fibers, the sperm specific glyceraldehyde-3-phosphate dehydrogenase in the fibrous sheath and glutathione peroxidase in the mitochondrial sheath), validating this proteomic approach. Other proteins corresponded to glycolytic enzymes. The glycolytic enzyme triose phosphate isomerase (TIM) and the voltage-dependent anion channel proteins (VDAC 2-3) were identified in spots highly fluorescent after DTT treatment; however the Cys-mBBr was not detected by the MS1 spectrum. In these spots, peptides of ODF1 were found.

Some spots with high fluorescence intensity had no protein identification through Mascot software search, although a good MS/MS spectrum was achieved. In these cases, we performed de novo sequencing (Table 2). These samples, as the $65 \mathrm{D}$ spot showed in Fig. 3, presented a similar peptides profile (Peptide-Mass Fingerprint) mainly by the presence of peaks with $m / z$ values of 1379,1246 and 1189. The first and the last peptide differ by $190 \mathrm{Da}$, consistent with the $\mathrm{mBBr}$ modification. The peptide with $m / z 1246$, which is 57 Da heavier than the $m / z 1189$ peptide (the thiol-free cysteine peptide), corresponds to a carbamidomethylation of the cysteine residue. De novo sequencing of the $\mathrm{m} / z 1189, \mathrm{~m} / z 1246.58$ and 1379.62 peptides showed a similar amino acid sequence-LALSCLLDSVR, in which the $y$ - and $b$-series ions were present (Fig. 3, Table 2). A protein BLAST search matched to the ODF1 from several species, including $E$. caballus with a $91 \%$ identity, differing only in the Leu2Ala. The immonium ion of the mBBr-modified cysteine was present in the MS/MS spectrum (Fig. 3). Upon manual sequencing, two additional peptides ( $\mathrm{m} / \mathrm{z} 1126.54$ and 936.46), differing by $190 \mathrm{Da}$ within the same MS spectrum, were shown to contain the sequence CIDELSTR. Also in this case, a BLAST search of this sequence matched to ODF1. Other proteins were also identified by this methodology (Table 2). 
Table 2

Protein identification of highly mBBr-labeled sperm samples, using de novo sequencing.

\begin{tabular}{|c|c|c|c|c|c|c|c|}
\hline Spot ID ${ }^{a}$ & Peptide sequence & MW theor & MW exp & $\mathrm{pI}$ theor & $\mathrm{p} I \exp$ & Accession number & $\begin{array}{l}\text { Protein } \\
\text { identification }\end{array}$ \\
\hline $41 \mathrm{~B}$ & $\begin{array}{l}\text { 1379.62-LALSC }{ }^{* *} \text { LLDSVR } \\
\text { 1246.58-LALSC }{ }^{*} \text { LLDSVR } \\
\text { 1189.57-LALSCLLDSVR } \\
\text { 1126.54-C }{ }^{* *} \text { IDELSTR } \\
\text { 936.46-CIDELSTR }\end{array}$ & 28.6 & 37.0 & 8.44 & 8.92 & 149721588 & $\begin{array}{l}\text { Outer dense fiber } \\
\text { protein } 1 \text {-like } \\
\text { [Equus caballus] }\end{array}$ \\
\hline $42 \mathrm{~B}$ & $\begin{array}{l}\text { 1379.62-LALSC }{ }^{* *} \text { LLDSVR } \\
\text { 1246.58-LALSC }{ }^{*} \text { LLDSVR } \\
\text { 1189.57-LALSCLLDSVR } \\
\text { 1126.54-C } \text { IDELSTR }^{* *} \text { 936.46-CIDELSTR }\end{array}$ & 28.6 & 37.0 & 8.44 & 8.92 & 149721588 & $\begin{array}{l}\text { Outer dense fiber } \\
\text { protein 1-like } \\
\text { [Equus caballus] }\end{array}$ \\
\hline $44 \mathrm{~B}$ & $\begin{array}{l}\text { 1379.62-LALSC }{ }^{* *} \text { LLDSVR } \\
\text { 1246.58-LALSC }{ }^{*} \text { LLDSVR } \\
\text { 1189.57-LALSCLLDSVR } \\
\text { 1126.54-C }{ }^{* *} \text { IDELSTR } \\
\text { 936.46-CIDELSTR }\end{array}$ & 28.6 & 35.4 & 8.44 & 9.77 & 149721588 & $\begin{array}{l}\text { Outer dense fiber } \\
\text { protein 1-like } \\
\text { [Equus caballus] }\end{array}$ \\
\hline $44 \mathrm{~B}$ & 2101.19-VNNASLIGLGYTQTLRPGVK & 30.8 & 35.4 & 8.94 & 9.77 & 338721036 & $\begin{array}{l}\text { Voltage-dependent } \\
\text { anion-selective } \\
\text { channel protein } \\
\text { 3-like isoform } 2 \\
\text { [Equus caballus] }\end{array}$ \\
\hline $51 \mathrm{~B}$ & $\begin{array}{l}\text { 1322.57-ILAFPCNQFGR } \\
\text { 1001.44-YAEC }{ }^{* *} \text { GLR } \\
\text { 811.37-YAECGLR }\end{array}$ & 29.2 & 23.2 & 10.38 & 9.0 & 3075478 & $\begin{array}{l}\text { Phospholipid } \\
\text { hydroperoxide } \\
\text { glutathione } \\
\text { peroxidase [Mus } \\
\text { musculus] }\end{array}$ \\
\hline $69 C$ & $\begin{array}{l}\text { 1126.64-C } \text { IDELSTR }^{* *} \text { ID } \\
\text { 936.55-CIDELSTR }\end{array}$ & 28.6 & 34.3 & 8.44 & 7.15 & 149721588 & $\begin{array}{l}\text { Outer dense fiber } \\
\text { protein } 1 \text {-like } \\
\text { [Equus caballus] }\end{array}$ \\
\hline $65 \mathrm{D}$ & $\begin{array}{l}\text { 1379.62-LALSC }{ }^{* *} \text { LLDSVR } \\
\text { 1246.58-LALSC LLDSVR } \\
\text { 1189.57-LALSCLLDSVR } \\
\text { 1126.54-C IDELSTR } \\
\text { 936.46-CIDELSTR }\end{array}$ & 28.6 & 35.2 & 8.44 & 6.93 & 149721588 & $\begin{array}{l}\text { Outer dense fiber } \\
\text { protein 1-like } \\
\text { [Equus caballus] }\end{array}$ \\
\hline $66 \mathrm{D}$ & $\begin{array}{l}\text { 1379.62-LALSC }{ }^{* *} \text { LLDSVR } \\
\text { 1246.58-LALSC LLDSVR } \\
\text { 1189.57-LALSCLLDSVR } \\
\text { 1126.54-C** IDELSTR } \\
\text { 936.46-CIDELSTR }\end{array}$ & 28.6 & 34.9 & 8.44 & 7.13 & 149721588 & $\begin{array}{l}\text { Outer dense fiber } \\
\text { protein } 1 \text {-like } \\
\text { [Equus caballus] }\end{array}$ \\
\hline 67D & $\begin{array}{l}\text { 1001.44-YAEC }{ }^{* *} \text { GLR } \\
\text { 811.37-YAECGLR }\end{array}$ & 29.2 & 22.0 & 10.38 & 7.16 & 3075478 & $\begin{array}{l}\text { Phospholipid } \\
\text { hydroperoxide } \\
\text { glutathione } \\
\text { peroxidase [Mus } \\
\text { musculus] }\end{array}$ \\
\hline
\end{tabular}

a A, B, C or D in the spot name refers to the spot excised from the gels shown in Fig. 2A, B, C and D, respectively.
Carbamidomethylated cysteine.

** MBBr-modified cysteine. 


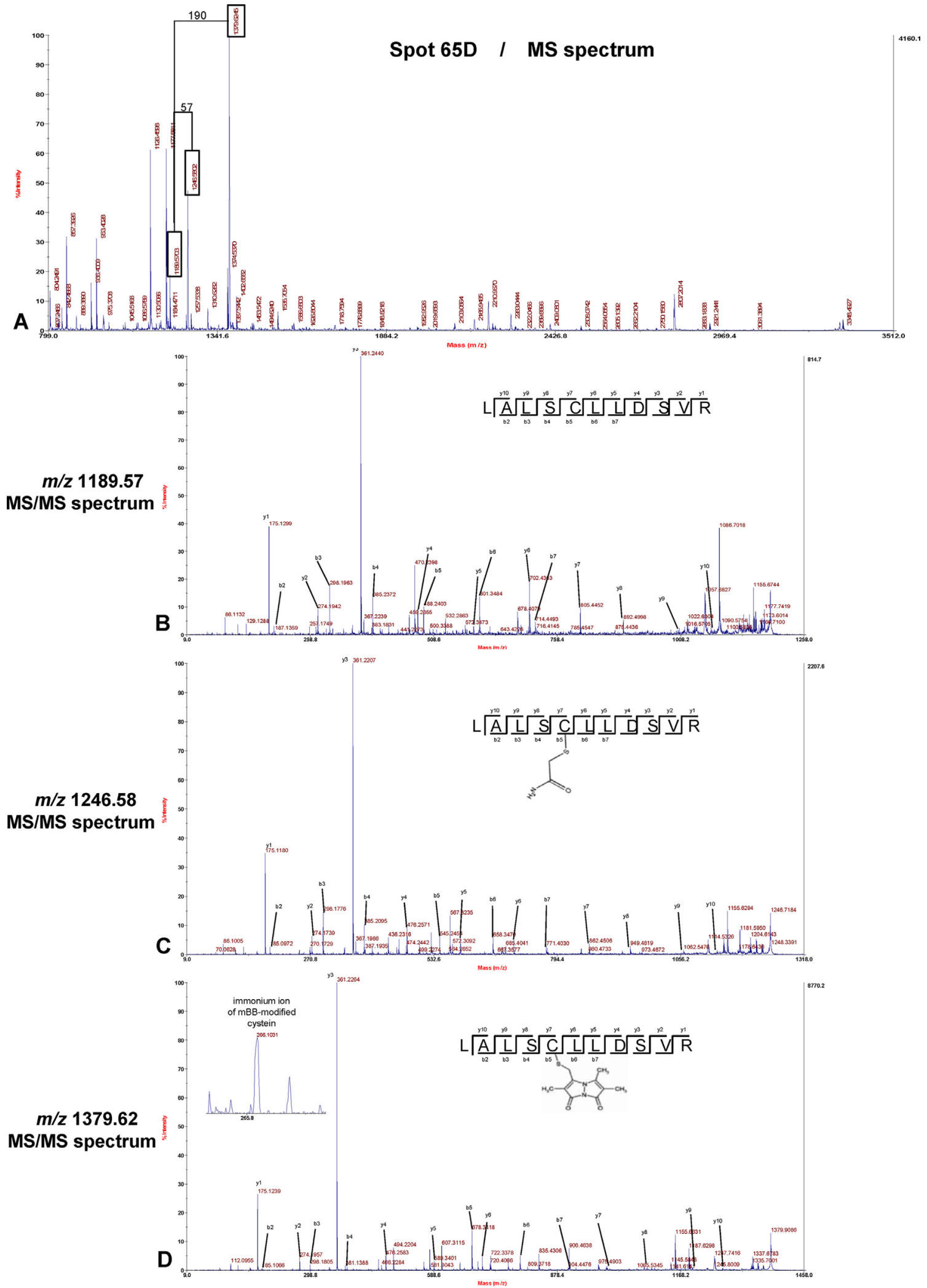

Fig. 3. (A) Peptide-mass fingerprint profile of the 65D fluorescent spot. The $m / z 1189.57,1246.58$ and 1379.62 peptides are highlighted as well as theirs molecular masses differences (daltons). The MALDI-TOF-MS analysis revealed that this spot correspond to the ODF1 protein. (B) MS/MS spectrum of the peptide $m / z 1189.57$; (C) MS/MS spectrum of the same peptide with carbamidomethylated cysteine; (D) the same peptide with a mBBr modified cysteine. 


\section{Discussion}

In the present work, the electrophoretic analysis of $\mathrm{mBBr}$-labeled sperm proteins (with and without reducing pre-treatment) demonstrated that some thiol proteins containing free - SH groups were modified through the formation of internal disulfides along the stallion epididymis. Densitometric analysis indicated that the total amount of sulphydrylated proteins in samples obtained from the caput, corpus and cauda epididymal regions was similar, but the magnitude of oxidation differed between proteins. Spermatozoa obtained from the cauda epididymis contained both $\mathrm{SH}$ and SS as indicated by the moderate decrease in fluorescence from caput to cauda and by enhancement in fluorescence following DTT treatment of cauda spermatozoa. These observations reinforce and complement our previous results that showed a decrease of the sulphydryl labeling in all the sperm domains during the stallion sperm maturation process (Dias et al., 2006). Seligman and Shalgi (1991) also showed prominent changes in the thiol status of rats epididymal spermatozoa and report that oxidation of the sperm thiol proteins from the caput epididymis improved the fertilizing ability, whereas a reduction of the cauda-sperm disulfides, by DTT, diminished the fertility (Seligman et al., 1997).

Our proteomic analysis revealed that the cytoskeleton protein ODF1 is the most sulphydrylated protein in stallion epididymal spermatozoa. The $\mathrm{mBBr}$ specifically bounded to N-terminal domain cysteine of ODF1 is responsible for the highly fluorescent $32 \mathrm{kDa}$ protein band. Cabrillana et al. (2011) report a 27 kDa ODF1 protein, displaying strong fluorescent signal in rat spermatozoa labeled by $\mathrm{mBBr}$. They also report that $\mathrm{mBBr}$ reduces rat sperm motility and the effects are dose dependent. ODF1 and AKAP4 probably contributed to the stabilization of outer dense fiber and fibrous sheath (FS) of sperm flagellum through the intermolecular disulfide bonds formed during sperm epididymal transit. AKAP4, the major fibrous sheath protein, seems to act also as a scaffold for both glycolytic enzymes and members of the signaling cascades that are positioned to provide a localized source of ATP and to play a role in the regulation of sperm motility (Brown et al., 2003; Cao et al., 2006; Krisfalusi et al., 2006). Multiple glycolytic enzymes, among them GAPDHS, are tightly bound to the FS at the principal piece of mouse, mice and human flagella (Krisfalusi et al., 2006) and are required for sperm motility (Miki et al., 2004). Our data indicate that GAPDHS also undergoes drastic thiol oxidation during sperm maturation. Proteins containing cysteines that may reversibly form disulfides are potential transmitter of redox signals, which may mediate events of the sperm maturation process.

Some proteins identified in highly fluorescent spots that undergo SH oxidation such as triosephosphate isomerase (TIM), voltage-dependent anion channel 2 and 3 (VDAC2, VDAC-3) had no mBBr-labeling detected through MS spectra analysis. Interestingly, in theses spot samples, the peptide modified by $\mathrm{mBBr}$ responsible for fluorescence corresponded to ODF1. This data suggests that these molecules may be associated corroborating the enzymes assembling theory. It has been suggested that the VDACs may transport the ATP from the mitochondria to the more distal dynein
ATPases of the flagellum and also protect the ATP from premature hydrolysis (Hinsch et al., 2004). The stabilization of the cytoskeletal structures, ODF and FS, seem to be accompanied by the organization of energy provider apparatus.

The presence of the $\mathrm{mBBr}$-labeled Ropporin together with AKAP4 in the same fluorescent spot may be explicated by the localization of this protein in the inner surface of the FS. They may form a complex in cytoskeletal components of the flagellum mediated by rhophilin, as was also suggested by Fujita et al. (2000). In our assays we also identified a protein similar to GST Mu-3 (GSTM3) ( 29kDa/pI 5.76). This protein already described as a FS component (Fulcher et al., 1995; Rowe et al., 1998), increased its fluorescence after the reducing pre-treatment. Multiple fluorescent spots of a same protein were observed; they could represent different isoforms or post-translationally modified proteins. Hemachand et al. (2002) provided evidences for the presence of two GST isoforms, Mu and Pi, on the plasma membranes of mature spermatozoa, which may mediate the binding of the zona pellucida to the sperm in addition to acting as a defense molecule. Many protein spots were identified as ODF1 or ODF2. The identification of a multiple form of ODF is not a new observation. For example, one dimensional immunoblot analysis of ODF2 shows a very diverse pattern of polypeptides of $\mathrm{Mr} \sim 20,000-90,000$ (Cao et al., 2006).

We demonstrated that the sperm $\sim 22-\mathrm{kDa}$ PHGPX underwent extensive - $\mathrm{SH}$ oxidation during epididymis travel. This result corroborates previous report in which has been shown that a soluble active PHGPx is converted into a structural enzymatically inactive protein by disulfide cross-linking in the mitochondria sheath of mature spermatozoa (Ursini et al., 1999).

In summary, these results have shown that several sperm proteins - among them motility and energy related proteins - undergo thiol-oxidation during the sperm maturation process in the epididymis. This phenomenon was more pronounced for polypeptides smaller than $33 \mathrm{kDa}$ that are associated to the cytoskeleton, energetic metabolism and antioxidant defense. The disulfide proteome suggest that pathways, as glycolysis, would be controlled by mechanism involving changes in the cysteine redox state of each enzyme implicated.

\section{Acknowledgments}

The authors wish to thanks to Prof. Dr Angelo B. Dias for their contribution in the stallion's surgical castration and the donation of the epididymides samples used in this study. This research has been partially supported by FAPERJ and UENF.

\section{Appendix A. Supplementary data}

Supplementary material related to this article can be found, in the online version, at http://dx.doi.org/10.1016/ j.anireprosci.2013.12.007.

\section{References}

Aitken, R.J., Vernet, P., 1998. Maturation of redox regulatory mechanisms in the epididymis. J. Reprod. Fertil. Suppl. 53, 109-118. 
Barford, D., 2004. The role of cysteine residues as redox-sensitive regulatory switches. Curr. Opin. Struct. Biol. 14, 679-686.

Brown, P.R., Miki, K., Harper, D.B., Eddy, E.M., 2003. A-kinase anchoring protein 4 binding proteins in the fibrous sheath of the sperm flagellum. Biol. Reprod. 68, 2241-2248.

Cabrillana, M.E., Monclus, M.A., Sáez Lancellotti, T.E., Boarelli, P.V., Clementi, M.A., Vicenti, A.E., Yunes, R.F.M., Fornés, M.W., 2011. Characterization of flagellar cysteine-rich sperm proteins involved in motility, by the combination of cellular fractionation, fluorescence detection, and mass spectrometry analysis. Cytoskeleton 68, 491-500.

Cao, W., Gerton, G.L., Moss, S.B., 2006. Proteomic profiling of accessory structures from mouse sperm flagellum. Mol. Cell Proteom. 5, $801-810$.

Cornwall, G.A., 2009. New insight into epididymal biology and function. Hum. Reprod. Upd. 15, 213-227.

Dias, G.M., Retamal, C.A., Tobella, L., Arnholdt, A., López, M.L., 2006. Nuclear status of stallion immature and mature spermatozoa. Theriogenology 66, 354-365

Fomenko, D.E., Marino, S.M., Gladyshev, V.N., 2008. Functional diversity of cysteine residues in proteins and unique features of catalytic redoxactive cysteines in thiol oxidoreductases. Mol. Cells 26, 228-235.

Fujita, A., Nakamura, K., Kato, T., Watanabe, N., Ishizaki, T., Kimura, K., Mizoguchi, A., Narumiya, S., 2000. Ropporin, a sperm-specific binding protein of rhophilin that is localized in the fibrous sheath of sperm flagella. J. Cell Sci. 113, 103-112.

Fulcher, K.D., Welch, J.E., Klapper, D.G., O’Brien, D.A., Eddy, E.M., 1995. Identification of a unique mu-class glutathione $\mathrm{S}$-transferase in mouse spermatogenic cells. Mol. Reprod. Dev. 42, 415-424.

Hemachand, T., Gopalakrishnan, B., Salunke, D.M., Totey, S.M., Shaha, C., 2002. Sperm plasma-membrane-associated glutathione Stransferases as gamete recognition molecules. J. Cell Sci. 115, 2053-2065.

Heo, L., Cho, Y.B., Lee, M.S., Roe, J.H., Seok, C., 2013. Alternative zinc-binding sites explain the redox sensitivity of zinc-containing anti-sigma factors. Proteins 81 (9), 1644-1652.

Hinsch, K.D., De Pinto, V., Aires, V.A., Schneider, X., Messina, A., Hinsch, E., 2004. Voltage-dependent anion-selective channels VDAC2 and VDAC3 are abundant proteins in bovine outer dense fibers, a cytoskeleton component of the sperm flagellum. J. Biol. Chem. 279, 15281-15288.

Jones, D.P., 2010. Redox sensing: orthogonal control in cell cycle and apoptosis signaling. J. Intern. Med. 268, 432-448.

Kosower, N.S., Kosower, E.M., 1987. Thiol labeling with bromobimanes. Methods Enzymol. 143, 76-84.

Krisfalusi, M., Miki, K., Magyar, P.L., O’Brien, D.A., 2006. Multiple glycolytic enzymes are tightly bound to the fibrous sheath of mouse spermatozoa. Biol. Reprod. 75, 270-278.

López, M.L., Olea, N., Retamal, C.A., 2007. Post-testicular changes in the density and distribution of intramembrane particles of stallion sperm domains. Anim. Reprod. Sci. 100, 204-210.

López, M.L., De Souza, W., 1991. Distribution of filipin-sterol complexes in the plasma membrane of stallion spermatozoa during the epididymal maturation process. Mol. Reprod. Dev. 28, 158-168.
López, M.L., De Souza, W., Bustos, E., 1987. Cytochemical analysis of the anionic sites on the membrane of the stallion spermatozoa during the epididymal transit. Gamete Res. 18, 319-332.

McKinnon, A.O., Squires, E.L., Vaals, W.E., Varner, D.D. (Eds.), 2011. Equine Reproduction., second edition. Wiley-Blackwell, West Sussex, UK.

Miki, K., Qu, W., Goulding, E.H., Willis, W.D., Bunch, D.O., Strader, L.F., Perreault, S.D., Eddy, E.M., O'Brien, D.A., 2004. Glyceraldehyde 3-phosphate dehydrogenase-S, a sperm-specific glycolytic enzyme, is required for sperm motility and male fertility. PNAS 101, 16501-16506.

Monteiro, H.P., Arai, R.J., Travassos, L.R., 2008. Protein tyrosine phosphorylation and protein tyrosine nitration in redox signaling. Antioxid. Redox. Signal 10, 843-889.

Petrotchenko, E.V., Pasek, D., Elms, P., Dokholyan, N.V., Meissner, G., Borchers, C.H., 2006. Combining fluorescence detection and mass spectrometric analysis for comprehensive and quantitative analysis of redox-sensitive cysteines in native membrane proteins. Anal. Chem. 78, 7959-7966.

Retamal, C.A., Dias, A.J.B., Brasil, F.C., Lanzana, F.R., López, M.L., 2012. Alpha mannosidase activity in stallion epididymal fluid and spermatozoa. Theriogenology 78, 252-262.

Retamal, C.A., Urzua, J., Lorca, C., López, M.L., Alves, E.W., 2000. Changes in the plasma membrane proteins of stallion spermatozoa during maturation in the epididymis. J. Submicrosc. Cytol. Pathol. 32, 229-239.

Retamal, C.A., Thiebault, P., Alves, E.W., 1999. Protein purification from polyacrylamide gels by sonication extraction. Anal. Biochem. 268, $15-20$.

Rowe, J.D., Patskovsky, Y.V., Patskovska, L.N., Novikova, E., Listowsky, I., 1998. Rationale for reclassification of a distinctive subdivision of mammalian class Mu glutathione S-transferases that are primarily expressed in testis. J. Biol. Chem. 273, 9593-9601.

Seligman, J., Newton, G.L., Fahey, R.C., Shalgi, R., Kosower, N.S., 2005. Nonprotein thiols and disulfides in rat epididymal spermatozoa and epididymal fluid: role of $\alpha$-glutamyl-transpeptidase in sperm maturation. J. Androl. 26, 629-637.

Seligman, J., Zipser, Y., Kosower, N.S., 2004. Tyrosine phosphorylation, thiol status, and protein tyrosine phosphatase in rat epididymal spermatozoa. Biol. Reprod. 71, 1009-1015.

Seligman, J., Kosower, N.S., Shalgi, R., 1997. Effects of castration on thiol status in rat spermatozoa and epididymal fluid. Mol. Reprod. Dev. 47, 295-301

Seligman, J., Shalgi, R., 1991. Protein thiols in spermatozoa and epididymal fluid of rats. J. Reprod. Fertil. 93, 399-408.

Sen, C.K., 2000. Cellular thiols and redox-regulated signal transduction. Curr. Top. Cell Regul. 36, 1-30.

Shalgi, R., Seligman, J., Kosower, N.S., 1989. Dynamics of the thiol status of rat spermatozoa during maturation: analysis with the fluorescent labeling agent monobromobimane. Biol. Reprod. 40, 10371045.

Ursini, F., Heim, S., Kiess, M., Maiorino, M., Roveri, A., Wissing, J., Flohé, L., 1999. Dual function of the selenoprotein PHGPx during sperm maturation. Science $285,1393-1396$ 